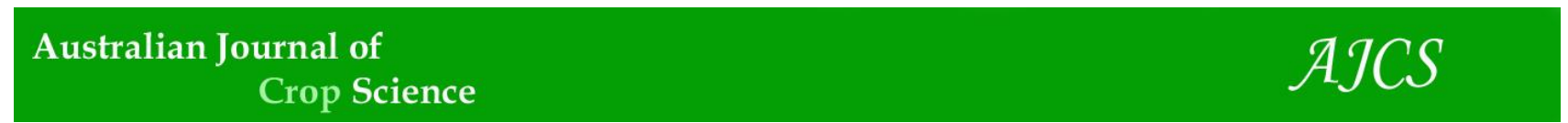

AJCS 14(03):537-544 (2020)

ISSN:1835-2707

doi: 10.21475/ajcs.20.14.03.p2239

\title{
IAA production of indigenous isolate of plant growth promoting rhizobacteria in the presence of tryptophan
}

\author{
Maria José Cavalcante da Silva ${ }^{1}$, Sebastião Ferreira Palmeira Junior ${ }^{2}$, Kleber Fortes Junior ${ }^{1}$, Velber Xavier \\ Nascimento* ${ }^{3}$, Amanda Silva de Medeiros ${ }^{3}$, Sarah Jacqueline Cavalcanti da Silva ${ }^{1}$, Maurício Marcelino de \\ Sousa Alves ${ }^{1}$, Antonio Eusebio Goulart Sant'Ana ${ }^{1}$
}

\author{
${ }^{1}$ Federal University of Alagoas, Maceió, AL, Brasil \\ ${ }^{2}$ Central Public Health Laboratory of Alagoas, LACEN, Maceió, AL, Brasil \\ ${ }^{3}$ University Center CESMAC, Maceió, AL, Brasil
}

*Corresponding author: velberxavier@gmail.com

Abstract

The plant growth-promoting rhizobacteria (PGPRBs) is an interesting way to promote increased vegetable production. Here, we aimed to isolate, identify, and characterize PGPRBs by using biochemical tests, sequencing of $16 \mathrm{~S}$ ribossomal DNA, in vitro and screening for indoleacetic acid production. The isolates were identified through VITEK ${ }^{\circledast} 2$ Compact equipment, which is an automated system. We identified microorganisms such as Alcaligenes faecalis sp. faecalis, Pseudomonas putida, Proteus vulgaris, Providencia rettgeri, Serratia marcescens e Myroides sp. by performing vitek 2 biochemical tests. The analysis of sequencing data for 16S ribossomal DNA of the isolated bacteria showed presence of A. faecalis, Myroides sp., P. putida, P. vulgaris, Providencia sp. and Serratia sp. The in vitro screening of all isolated bacteria showed production of indoleacetic acid under presence of tryptophan, highlighting that higher concentrations were produced by Providencia sp. and Myroides sp. The rhizobacteria studied here have shown the potential to be used in the development of new products for plant growth-promoting.

Keywords: Biochemical analysis; Enterobacter; Klebsiella; phytohormones; rhizospheric bacteria.

Introduction

The knowledge of biodiversity and bioprospecting of new micro-organisms have become one of the main focuses of the biotechnology era as application of organisms in areas of food, health, environment and industry are growing rapidly (Oliveira et al., 2006; Prathap and Ranjitha Kumari, 2015). Plant growth is influenced by the interaction of aerial parts through photosynthesis and roots with the rhizospheric environment through soil or planting substrate, which provides physical support and do offer water and nutrients to the plant, interacting with a complex of microorganisms (Luster et al., 2009). Rhizobacteria Plant Growth Promoter (PGPR) are stimulated by radicular pseudo exudates, colonizing the root system and promoting the growth of the plants, making them more vigorous, productive and healthy (Vazquez et al., 2000; Oliveira, 2004; Hayat et al., 2010; Backer et al., 2018).

The mechanisms responsible for the promotion of plant growth by bacteria often includes production of indoleacetic acid (IAA) by the enzyme indolpyruvate decarboxylase in the presence of the amino acid tryptophan (Spaepen et al., 2009; Prathap and Ranjitha Kumari, 2015). Its main effect is to promote the growth of roots and stems, by stretching the newly formed cells in the meristems (Barazani and Friedman, 1999). The phosphate solubilization can take place due to secretion of organic acids and phosphatases by some PGPRs, facilitating the conversion of the insoluble forms to soluble, making this nutrient available to the plants (Souchie et al., 2005). This is fundamentally important because $P$ is the second mineral that ts absence can limit plant growth (Chen et al., 2006). It is also affects production of diffusible antibiotics (Ahmad et al., 2008) and lytic enzymes such as chitinases (Kavino et al., 2010) to provide an efficient biological control of phytopathogens in nature (Bakker et al., 2007).

Bacterial isolates that produce IAA have stimulatory effects on plant growth. In wheat, bacterial isolates that produce high amounts of auxins on unsterilized soils, cause the maximum increase and development in the crop growth (Khalid et al., 2004). Even isolates that produce low amounts of IAA, their continuous release promotes plant growth (Tsavkelova et al., 2007).

Patten and Glick (2002) found that application of Pseudomonas putida increased the primary growth of canola roots (Brassica campestris) from $35 \%$ to $50 \%$ due to the production of IAA. They directly demonstrated that the bacterial phyto-regulator plays an important role in root elongation when the bacterium is associated with the host plant. Similar effect was obtained by Cattelan (1999), with different isolates of Pseudomonas spp. in soybean.

The rhizobacteria of the genus Serratia $\mathrm{sp}$ have been included among the phytormonium producers (Srinivasan et al., 1996; Buchenauer 1998). The potential of Serratia 
marcescens isolate for cold tolerance and promotion of wheat growth was evaluated and significant increase in biomass and nutrient absorption along with increase in nutrient absorption was observed in wheat seedlings at 4 ㅇ․ This phenomenon was attributed to the ability of the isolate to produce IAA and to solubilize phosphate, which positively influences the growth and development of the roots.

In addition to the effects on plant size and development, auxin of bacterial origin plays an important role in seed germination. Azospirillum brasilense Az39 and Bradyrhizobium japonicum E109, are capable of excreting IAA in culture medium in a concentration sufficient to produce morphological and physiological changes in young maize (Zea mays L.) seeds tissue (Cassán et al., 2009).

This study aimed at isolation and identification of rhizobacteria and to verify the mechanisms of action such as production of indoleacetic acid to promote plant growth using biochemical and molecular tools.

\section{Results and discussions}

\section{Biochemical and molecular identification of rhizobacteria isolation}

According to the biochemical tests, the following species/isolates were identified: Alcaligenes faecalis ssp. faecalis isolate (99\% probability), isolate Myroides spp. (98\% probability), Pseudomonas putida (99\% probability), Proteus vulgaris $(99 \%$ probability), Providencia rettgeri $(99 \%$ probability), and Serratia marcescens. The results were satisfactory since it is recommended that the accuracy of an automated system exceeds $90 \%$. Some reports have confirmed that system had ability to identify commonly isolated organisms, with at least $95 \%$ accuracy compared to the conventional method (O'hara, 2006; Otto-Karg 2009).

In order to confirm the biochemical identifications, molecular tests were performed, based on the 16S rDNA of the isolates. From the partial amplification of the $16 \mathrm{~S}$ rDNA gene by PCR generated fragments of approximately 550 base pairs (bp) for the six rhizobacteria isolates (Fig 1).

The nucleotide sequences corresponding to the PCR products of each isolate were determined by sequencing and submitted to the BLASTn algorithm. Species that shared more than 95\% nucleotide identity with the six bacterial isolates were selected for pairwise sequence analysis (PASC). In the PASC analysis, the isolate $1 \mathrm{~A}$ (gb|KC693027) was closer to the species: Alcaligenes faecalis, A. faecalis subsp. faecalis, A. faecalis subsp. parafaecalis with $99 \%$ nucleotide identity. However, it was not possible to characterize its subspecies. This result corroborates with the biochemical analysis, which identified this isolate as $A$. faecalis subsp. faecalis, with $99 \%$ probability.

The sequence of isolate $2 \mathrm{~A}$ (gb|KC693028) has proved $100 \%$ identity to the species Myroides odoratus. This isolate, belonged to the genus Myroides spp. by biochemical tests. Isolate 4A (gb|KC693026), shared $100 \%$ identity with the species Pseudomonas putida and P. rhizosphaerae. By biochemical tests this isolate was identified as $P$. putida with $99 \%$ probability.

Isolate $5 \mathrm{~A}(\mathrm{gb} \mid \mathrm{KC} 693029)$ has proved $100 \%$ identity to the species Proteus penneri and $P$. vulgaris. This isolate was biochemically characterized as $P$. vulgaris with $99 \%$ probability. Isolate 6A (gb|KC693030) proved 97\% identity with the species Providencia rettgeri and P. vermicola.
Biochemical analysis identified this species as $P$. rettgeri with 99\% probability. Finally, isolate $8 \mathrm{~A}$ (gb|KC693031) shared $100 \%$ identity with Serratia marcescens and $S$. nematodiphila. However, $8 \mathrm{~A}$ isolate was biochemically identified as Serratia marcescens with $95 \%$ probability.

Phylogenetic analysis revealed the distribution of the six isolates in six different groups, which corresponded to the genus Alcaligenes sp., Pseudomonas sp., Proteus sp., Providencia sp., Serratia sp., and Myroides sp. (Fig 2).

Group 1, represented by genus Alcaligenes, including isolate $1 \mathrm{~A}$ (gb|KC693027) which grouped in a branch with $100 \%$ probability with the species $A$. faecalis, $A$. faecalis subsp. faecalis and $A$. faecalis subsp. parafaecalis. Alcaligenes faecalis is related to the biological control against pathogens and the promotion of plant growth (Honda et al., 1998; Sayyed et al., 2010; Gholamalizadeh et al., 2017). The plant growth promoting characteristics of $A$. faecalis includes production of AIA and phosphate solubilization (Sayyed et al., 2010; Gholamalizadeh et al., 2017). The isolate $4 \mathrm{~A}$ (gb|KC693026) classified in the second group, represented the genus Pseudomonas, grouping with $88 \%$ probability with two species of $P$. putida, which is an important plant growth promoting bacterium (Matilla et al., 2011; HernándezMontiel et al., 2017) and P. rhizosphaerae, isolated bacterium of marine environment, which has been reported as a potential biocontrol agent (Paternoster et al., 2010). The third group represented by the genus Proteus sp., included isolated 5A (gb|KC693029), grouped with the species $P$. penneri and $P$. vulgaris. The $P$. vulgaris and $P$. penneri species are closely related, being differentiated by the production of indole, salicin, esculin and resistance to chloramphenicol, which are not synthesized by the last one (Hickman, 1982). The production of auxin (indole-3-acetic acid) via tryptophan was detected by isolate $5 \mathrm{~A}$ (Fig 3 ), indicating as indole positive. This fact contributes to increasing the possibility of this isolate belonging to $P$. vulgaris specie. Isolate $6 \mathrm{~A}$ (gb|KC693030) was placed in the fourth group, represented by the genus Providencia sp., which is next to the group of the species $P$. rettgeri and $P$. vermicola. $P$. rettgeri. It is an opportunistic pathogen associated with human urinary tract infections (Manos and Belas, 2006). P. rettgeri found in association with Nicotiana tabacum (tobacco) was able to phosphate-solubilizing and siderophore production showing its potential as promoting plant growth (Gao et al., 2016). However, P. vermicola, presented deaminase activity, which caused the increase in the size and number of mung bean (Vigna radiata) roots (Akhtar and Ali, 2011). It has reportedly promoted the germination of cauliflower and cabbage seeds (Gowtham et al., 2015). The fifth group corresponded to the genus Serratia sp., where it was grouped the isolate $8 \mathrm{~A}$ (gb) KC693031) along with S. marcescens and S. nematodiphila. The two of the bacteria commonly reported as plant growth promoters by inducing resistance against plant pathogens, production of antagonist substances (Queiroz and Melo, 2006), phosphate solubilization and auxin production (Tripura et al., 2007; Dastager et al., 2011; Khan et al. 2017; Santosa et al., 2018).

The sixth and last group was represented by the genus Myroides. The isolate $2 \mathrm{~A}$ (gb|KC693028) was identified as belonging to the species Myroides odoratus, with $93 \%$ of reliability based on phylogenetic analysis of rRNA. Myroides odoratus has been reported as an opportunistic pathogen related to hospital infections, in addition to being able to 


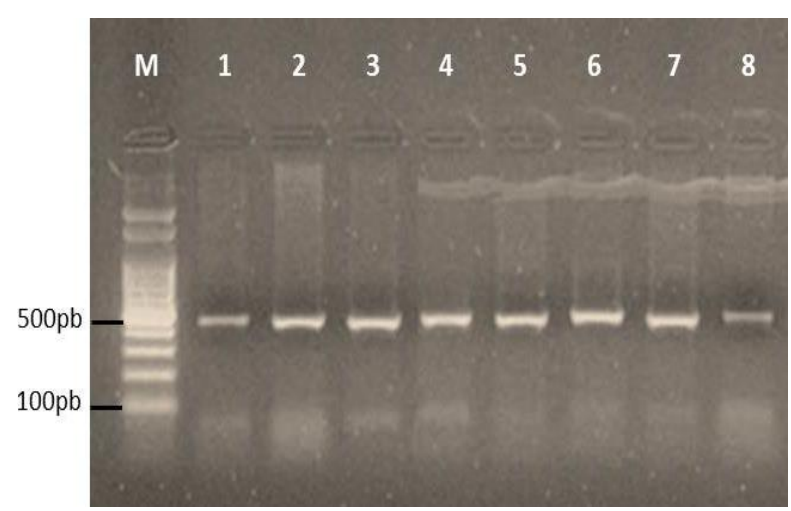

Fig 1. Electrophoretic PCR pattern of 500bp fragments of the DNAr16S gene on 1.2\% agarose gel. (M) Molecular weight marker (100pb). The numbers $1,2,3,4,5,6,7$ and 8 , represent the isolates $1 \mathrm{~A}, 2 \mathrm{~A}, 3 \mathrm{~A}, 4 \mathrm{~A}, 5 \mathrm{~A}, 6 \mathrm{~A}, 7 \mathrm{~A}$ and $8 \mathrm{~A}$, respectively.

\begin{tabular}{|c|c|c|c|c|c|c|c|c|c|c|c|c|c|c|c|c|c|c|c|c|c|c|}
\hline Bactéria & $1 \mathrm{~A}$ & $2 \mathrm{~A}$ & $4 \mathrm{~A}$ & $5 \mathrm{~A}$ & $6 \mathrm{~A}$ & $8 \mathrm{~A}$ & Ser N & Ser M & Prov V & Prov $\mathrm{R}$ & Prot P & Prot V & Alc F & Alc FSF & Alc FSP & Pseud $\mathrm{F}$ & Pseud S & Pseud P & Pseud R & Myr M & Myr OM & Myr OT \\
\hline $1 \mathrm{~A}$ & 100 & & & & & & & & & & & & & & & & & & & & & \\
\hline $2 \mathrm{~A}$ & 74 & 100 & & & & & & & & & & & & & & & & & & & & \\
\hline $4 \mathrm{~A}$ & 88 & 80 & 100 & & & & & & & & & & & & & & & & & & & \\
\hline $5 \mathrm{~A}$ & 79 & 79 & 85 & 100 & & & & & & & & & & & & & & & & & & \\
\hline $6 \mathrm{~A}$ & 80 & 77 & 85 & 94 & 100 & & & & & & & & & & & & & & & & & \\
\hline $8 \mathrm{~A}$ & 81 & 77 & 85 & 94 & 96 & 100 & & & & & & & & & & & & & & & & \\
\hline Ser N & 81 & 78 & 85 & 94 & 96 & 100 & 100 & & & & & & & & & & & & & & & \\
\hline Ser M & 81 & 78 & 85 & 94 & 96 & 100 & 100 & 100 & & & & & & & & & & & & & & \\
\hline Prov V & 82 & 78 & 86 & 95 & 97 & 98 & 98 & 98 & 100 & & & & & & & & & & & & & \\
\hline Prov $\mathrm{R}$ & 81 & 78 & 85 & 95 & 97 & 98 & 98 & 98 & 99 & 100 & & & & & & & & & & & & \\
\hline Prot P & 79 & 79 & 85 & 100 & 94 & 94 & 94 & 94 & 95 & 95 & 100 & & & & & & & & & & & \\
\hline Prot $V$ & 79 & 79 & 85 & 100 & 94 & 94 & 94 & 94 & 95 & 95 & 100 & 100 & & & & & & & & & & \\
\hline Alc F & 99 & 74 & 87 & 79 & 80 & 81 & 81 & 81 & 99 & 80 & 79 & 79 & 100 & & & & & & & & & \\
\hline Alc FSF & 99 & 74 & 87 & 79 & 80 & 81 & 81 & 81 & 99 & 80 & 79 & 79 & 100 & 100 & & & & & & & & \\
\hline Alc FSP & 99 & 74 & 87 & 79 & 80 & 81 & 81 & 81 & 99 & 80 & 79 & 79 & 100 & 100 & 100 & & & & & & & \\
\hline Pseud F & 87 & 80 & 99 & 85 & 85 & 85 & 85 & 85 & 85 & 85 & 85 & 85 & 87 & 87 & 87 & 100 & & & & & & \\
\hline Pseud S & 88 & 80 & 99 & 85 & 85 & 85 & 85 & 85 & 86 & 85 & 85 & 85 & 87 & 87 & 87 & 99 & 100 & & & & & \\
\hline Pseud P & 88 & 80 & 100 & 85 & 85 & 85 & 85 & 85 & 86 & 85 & 85 & 85 & 87 & 87 & 87 & 99 & 99 & 100 & & & & \\
\hline Pseud R & 88 & 80 & 100 & 85 & 85 & 85 & 85 & 85 & 86 & 85 & 85 & 85 & 87 & 87 & 87 & 99 & 99 & 99 & 100 & & & \\
\hline Myr M & 74 & 96 & 79 & 77 & 77 & 76 & 77 & 77 & 77 & 77 & 78 & 78 & 73 & 73 & 73 & 79 & 79 & 79 & 79 & 100 & & \\
\hline Myr OM & 73 & 95 & 79 & 77 & 76 & 76 & 76 & 76 & 77 & 77 & 78 & 78 & 72 & 76 & 72 & 79 & 79 & 79 & 79 & 99 & 100 & \\
\hline Myr OT & 74 & 100 & 80 & 79 & 77 & 77 & 78 & 78 & 78 & 78 & 79 & 79 & 74 & 74 & 74 & 80 & 80 & 80 & 80 & 96 & 96 & 100 \\
\hline
\end{tabular}

Fig 2. Comparisons of nucleotide sequences of the $16 \mathrm{~S}$ DNAr gene among six rhizobacterial isolates of this work and other bacteria available from GenBank. 1, 2, 4, 5, 6, 8, bacterial isolates belonging to this work; Ser N - Serratia nematodiphila; Ser M - Serratia marcescens; Prov V - Providencia vermicola; Pro R - Providencia rettgeri; Alc F - Alcaligenes faecalis; Alc FSF - Alcaligenes faecalis subsp. faecalis; Alc FSP - Alcaligenes faecalis subsp. parafaecalis; Pseud F - Pseudomonas fluorescens; Pseud S - Pseudomonas syringae; Pseud P-Pseudomonas putida; Pseud R-Pseudomonas rhizosphaerae; Myr M-Myroides marinus; Myr OM - Myroides odoratimimus; Myr OT - Myroides odoratus.

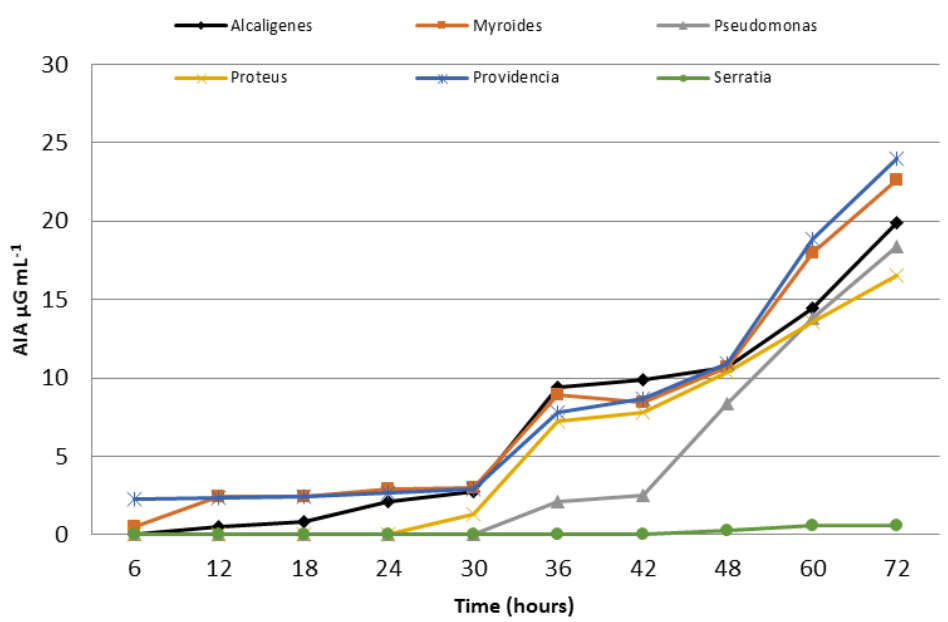

Fig 3. Growth dynamics and IAA concentration of the six isolates, monitored by OD measurement at 600nm, at intervals of 6 hours of growth and concentration of IAA at $530 \mathrm{~nm}$. 


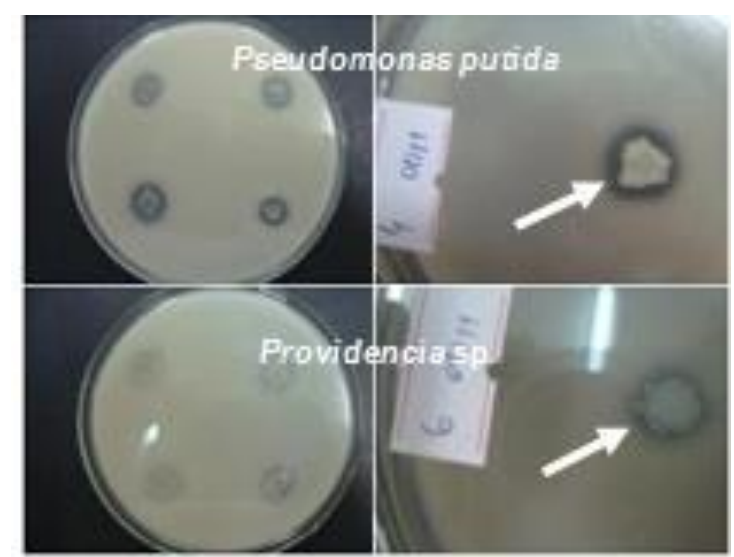

Fig 4. Solubilization halos of inorganic phosphate $(\mathrm{CaHPO} 4)_{2}$ by Pseudomonas putida and Providencia sp. isolates grown in NYDA pH 7.0 at $28 \circ \mathrm{C}$ for seven days.

produce biofilm (Jacobs and Chenia, 2009). However, $M$. odoratus obtained from rice rhizosphaere was able to produce IAA and beta-1,3 glucanase showing potential to act in the promotion of plant growth and as a biocontrol agent (Amruta et al., 2018). PASC and phylogenetic analysis based on the partial sequence of the 16r rDNA gene allowed the identification at the genus level of the six rhizobacteria isolates. However, it was not possible to confirm the identity of the species which has been found by biochemical methods.

\section{Colorimetric quantification of IAA synthesized via tryptophan}

All the isolates studied in this research were able to produce IAA. However, the production of the Serratia isolate was incipient $\left(0.6 \mu \mathrm{g} \cdot \mathrm{mL}^{-1}\right)$. The highest concentrations of IAA were obtained by the Providencia isolate, which reached 24 $\mu \mathrm{g} \cdot \mathrm{mL}^{-1}$ followed by Myroides $24 \mu \mathrm{g} \cdot \mathrm{mL}^{-1}$, Alcaligenes 20 $\mu \mathrm{g} \cdot \mathrm{mL}^{-1}$, Pseudomonas $18.37 \mu \mathrm{g} \cdot \mathrm{mL}^{-1}$, and Proteus 16.53 $\mu \mathrm{g} \cdot \mathrm{mL}^{-1}$, at $72 \mathrm{~h}$ growth. This result is in agreement with the literature showing that more than $80 \%$ of the bacteria isolated from the rhizosphere are capable of producing the AIA growth regulator (Barazani and Friedman, 1999; Khalid et al., 2004; Panhwar, 2014).

Rhizosphere bacteria, which produce IAA, can perform functions in promoting plant growth, especially in the early stages of development and in the rooting process. It is known that this stimulus is dependent on the amount of hormone produced, since the excess of it can delay or even inhibit the growth of the plant (Trabelsi, 2017).

In plants, the microbial IAA produced by bacteria of the genus Azospirillum, Alcaligenes faecalis, Klebsiella, Enterobacter, Acetobacter diazotrophicus, Pseudomonas, Enterobacter Xanthomonas, Herbaspirillum seropedicae, Rhizobium and Bradyrhizobium sp., has been related to the growth stimulus. The quantities of IAA excreted by the isolates depend on the species or even the strain under study, as well as on the conditions, under which organisms are cultured, such as presence or absence of the IAA precursor in the culture medium (tryptophan), oxygenation, $\mathrm{pH}$ and growth phase in which the isolates (Pedraza et al., 2004) are found.

The results observed for the isolates of Providencia and Myroides, overpassed most reports in the literature. Several studies have identified bacterial strains producing IAA,
(Rocha et al., 2011; Oliveira, 2009; Verma et al., 2001; Xie et al., 1996; Fuentes-Ramirez et al., 1993; Fett et al., 1987).

The species Pseudomonas putida has been observed as a merit producer of IAA, reaching IAA levels of $14.5 \mu \mathrm{g} \cdot \mathrm{mL}^{-1}$ with $50 \mu \mathrm{g} \cdot \mathrm{mL}^{-1}$ of Trp; $22.5 \mu \mathrm{g} \cdot \mathrm{mL}^{-1}$ with 100 of Trp and 26.2 $\mu \mathrm{g} \cdot \mathrm{mL}^{-1}$ with $220 \mu \mathrm{g} \cdot \mathrm{mL}^{-1}$ of $\operatorname{Trp}$ (Patten and Glick, 2002). Contrarily, this species presented lower results in this study. The bacterial IAA is a secondary metabolite and is therefore produced in the stationary phase of bacterial growth. However, the duration of the stationary phase depends on each species. Thus, it is necessary to know the behavior of each isolate, to read auxin synthesis at different times of bacterial development. It makes determination of period, during which maximum hormone synthesis occurs, possible (Cerigioli, 2005). In addition to, the knowledge of the stationary phase for auxin reading, the growth curve provides the relationship between bacterial density and hormone production.

The isolates of Alcaligenes, Myroides, Pseudomonas, Proteus and Providencia (Fig 4) started a production before bacterial growth and reached a stationary phase. This effect may be related to the culture medium used for the bacterial growth (nutrient broth) containing yeast extract, rich source of amino acids and tryptophan (Yamada et al., 2003). It was observed that the concentrations of IAA was increased starting from 30 hours of incubation and optical density between 0.5 and 2.0 and were not observed in the production. The levels of IAA produced by bacteria depend on the bacterial growth, metabolic activity and the expression of genes that encode enzymes for an IAA biosynthesis (Lambrecht et al., 2000). Hence, a nutritional deficiency may inhibit a production of this phytohormone.

The amounts of IAA excreted by the isolates depend on the species or even the strain under study, as well as on the conditions, under which the organisms are cultivated, such as: presence or absence of the IAA precursor in the culture medium (tryptophan), oxygenation, $\mathrm{pH}$ and growth phase (Pedraza et al., 2004).

\section{Phosphate solubilization test}

Only the isolates of P. putida and Providencia presented a halo around the colonies ( 13.5 and $8.8 \mathrm{~mm}$, respectively) indicating the phosphate solubilization potential (Fig 4). These solubilization halos were superior to those observed by Silva Filho and Vidor (2000), Massenssini et al. (2008), in 
which halo diameters ranged from 2 to $7 \mathrm{~mm}$ for Pseudomonas, and 2 to $5 \mathrm{~mm}$ for Bacillus.

This ability has been attributed to the ability to change the $\mathrm{pH}$ of the medium through the release of organic acids such as citrate, lactate, succinate (Hariprasad and Niranjana, 2009). However, acid phosphatases are of great importance for organic phosphorus mineralization (Souchie et al., 2005). The solubilization of calcium phosphate may have contributed to the greater availability of this element, increasing resistance to disease. This is a fact that should be observed is the ability of these bacteria to facilitate the absorption of calcium by the plant.

The proposed work on growth-producing bacteria revealed that $A$. faecalis sp faecalis, Myroides sp, Pseudomonas putida, Proteus vulgaris, and Providencia $\mathrm{sp}$ isolates produced significant amounts of IAA. In addition, the isolates of Pseudomonas putida, and Providencia sp were able to solubilize phosphate. This is the first report of Myroides sp. as rhizobacteria growth promoter and producer of IAA, and Providencia sp as phosphate solubilizer.

\section{Materials and methods}

\section{Isolation of rhizobacteria}

The isolates used in this study were removed from the roots of vegetable crops and stored in nutrient broth (bacterial pools).

In the isolation process, a $100 \mu \mathrm{L}$ aliquot of each pool was distributed in a $9.0 \mathrm{~cm}$ diameters Petri dishes, with different blood agar and Levine culture medium (prepared according to the manufacturers recommendations), scattered with Drigalsky spatula. The cultures were incubated in a BOD incubator at $28{ }^{\circ} \mathrm{C}$. The same procedure was repeated in CHROMagar BD medium, where the colonies formed with different staining and morphology were repeated with platinum loop. Sequentially, the procedure was conducted to the BD CHROMagar medium and to the media -BD MPacAgar-Pseudomonas and Agar-Cled- BIOGEN, because they are medium deficient in electrolytes making possible the isolation of the genus Proteus sp. The present isolates are mobile, facilitating the contamination between them. Subsequently, the isolates were submitted to the Gram test.

\section{Biochemical tests for identification of isolates}

Biochemical analysis were performed using the VITEK $^{\circledR} 2$ Compact equipment (bioMérieux, Inc.) (Crowley et al., 2012). Colonies of each isolate with 18-24 hours of culture were resuspended in $\mathrm{NaCl}-0.85 \%$ in a test tube to be connected through a small tube to the biochemical card for Gram- or + bacteria (already Identified by the Gram staining test) and then placed in VITEK ${ }^{\circledR} 2$ system for reading and identification of the isolates, according to the manufacturer's specifications.

\section{$16 S$ rDNA sequence analyzes}

\section{DNA extraction}

Total genomic DNA was extracted according to the protocol of Ausubel et al. (2003) and quantified on $8 \%$ agarose gel in
Tris Acetate EDTA buffer (TAE) and stained with $0.5 \mu \mathrm{g} / \mathrm{ml}$ ethidium bromide.

\section{S rDNA bacterial amplification}

Approximately $500 \mathrm{pb}$ amplification of the bacterial DNA of the $16 \mathrm{~S}$ region was performed using the universal primers EUBF 933: 5 'GCACAAGCGGTGGAGCATGTG and EUBr 1387: 5' GCCCGGGAACGTATTCACCG (Iwamoto et al., 2000).

The reactions were carried out to a final volume of $50 \mu \mathrm{L}$ in 35 cycles of amplification, in four distinct stages: Denaturation of the viral DNA strand at $94{ }^{\circ} \mathrm{C}$ for 30 seconds, ringing the primers at $56{ }^{\circ} \mathrm{C}$ for 1 minute, extension of new DNA strands at $72{ }^{\circ} \mathrm{C}$ for 1 minute and final extension at 72 oC for 10 minutes.

\section{Bacterial 16S DNA fragment sequencing}

The Direct sequencing of PCR products was performed by MACROGEN Inc., Seoul, South Korea. Sequences obtained were aligned with sequences deposited in the GenBank / NCBI database (www.ncbi.nlm.nih.gov/) "National Center for Biotechnology Information "using the BLAST tool," Basic Local Alignment Search Tool ".

To determine the percentage of nucleotide sequence identity between the bacterial isolates of this work and other bacterial sequences deposited in GenBank, additional pairwise nucleotide pairwise analysis were performed with the DNAMan v.6.0 (LynnonCo.) program, using the optimal alignment option following parameters: Ktuple $=2$, Gap penalty $=7$, Gap open $=10$, Gap extension $=5$.

\section{Phylogenetic analysis}

Phylogenetic analysis consisted of the construction of a tree based on the "Maximum Likelihood" method, using approximately 400 nucleotides from the DNAr 165 region of the isolates and other nucleotide sequences from more closely related bacteria already deposited in GenBank. For maximum likelihood analysis, the nucleotide sequences were initially aligned with the MUSCLE tool available in the MEGA 5.05 program.

Alignment was later used to determine the best nucleotide substitution model with the "Find Best-Fit Substitution Model" tool available in the same program. The best substitution model chosen was the Kimura 2 parameters, which takes into account the transitional substitution rates (A $<->G$, purine for purine, or $T<->C$, pyrimidine for pyrimidine) and transverse substitution rates (purine to pyrimidine, or vice versa). The model also assumes that all bases are equally frequent (Kimura, 1980). The reliability of the tree branches was calculated by bootstrap analysis with 10,000 replications.

\section{Indoleacetic acid (IAA) colorimetry quantification}

Each isolate was multiplied by the striped method in Petri dishes under nutritive medium agar-dextrose-yeast extract NYDA. The colonies with 24 hours growth were removed from the surface of the culture medium with platinum handler and placed in test tubes with $0.5 \mathrm{~mL}$ sterile distilled water (SDW). The bacterial suspension was prepared so as to 
obtain a standard concentration of $10^{7}$ colony forming units (CFU) / $\mathrm{ml}$, according to the MacFarland Scale.

Aliquots of $13 \mathrm{~mL}$ of bacterial suspension were collected every six hours, and then agitated for five minutes. Then 3 $\mathrm{mL}$ of aliquots was taken for optical density (OD) quantification at $600 \mathrm{~nm}$, and $10 \mathrm{~mL}$ centrifuged at 7,000 $\mathrm{xg}$ for 10 minutes at $15{ }^{\circ} \mathrm{C}$ and the supernatant collected for analysis of the IAA quantification. The quantity of IAA per ml of the culture supernatant was estimated with the modified Gordon and Weber protocol (Gordon and Weber, 1951).

The color intensity was determined on spectrophotometer, UV / VIS (Perkin Elmer UV / VIS Lambda 2), with absorbance reading at $530 \mathrm{~nm}$. The nutrient broth $(1 \mathrm{~mL})$ was used as a "white" and nutrient broth with addition of $200 \mu \mathrm{g} \mathrm{mL}^{-1}$ tryptophan $(1 \mathrm{~mL})$ as negative control. The IAA concentration was estimated using a standard curve, prepared with the culture medium, with addition of $200 \mu \mathrm{g} \mathrm{mL}^{-1}$ of tryptophan and known amounts of the hormone, which were obtained by dilutions of 1.0 to $200 \mathrm{mg} \mathrm{mL}$ - (Sigma-Aldrich). The experimental design was completely randomized with eight treatments and three replicates. The analysis were performed using the statistical software SISVAR ${ }^{\circledast}$ version 5.3.

\section{Conclusions}

Information obtained through biochemical tests allowed the isolates to be identified as Alcaligenes faecalis ssp. faecalis, Pseudomonas putida, Proteus vulgaris, Providencia rettgeri, Serratia marcescens and Myroides sp. The sequencing of 165 rDNA gene was not capable of identify all species. Isolates of A. faecalis ssp. faecalis, Myroides sp., P. putida, P. vulgaris and Providencia sp. produced IAA in significant amounts. The isolates of Pseudomonas putida and Providencia sp. were able to solubilize phosphate. The rhizobacteria interfered positively in the development of collard greens, bell pepper and tomato seedlings, in which the Providencia sp. isolate, stood out. This is the first report of Myroides sp. as growth promoting rhizobacteria and IAA producer, and Providencia sp. as phosphate solubilizer.

\section{Acknowledgment}

Federal University of Alagoas, Maceió, AL, Brasil.

\section{References}

Ahmad F, Ahmad I, Khan MS (2008) Screening of free-living rhizospheric bacteria for their multiple plant growth promoting activities. Microbial Research. 163:173-181.

Akhtar S, Ali B (2011) Evaluation of rhizobacteria as nonrhizobial inoculants for mung beans. Australian Journal of Crop Science. 5:1723-1729.

Amruta N, Kumar MKP, Puneeth ME, Sarika G, Kandikattu HK, Vishwanath K, Narayanaswamy S (2018) Exploring the Potentiality of Novel Rhizospheric Bacterial Strains against the Rice Blast Fungus Magnaporthe oryzae. Plant Pathol. J. 34: 126-138.

Ausubel FM, Brent R, Kingston RE, Moore DD, Seidman JG, Smith JA, Struhl K (2003) Current protocols in molecular biology. New Jersey, December 2003.

Backer R, Rokem S, Ilangumaran G, Lamont J, Praslickova D, Ricci E, Subramanian S, Smith DL (2018) Plant GrowthPromoting Rhizobacteria: Context, Mechanisms of Action, and Roadmap to Commercialization of Biostimulants for Sustainable Agriculture. Front. Plant Sci. 9:1473.

Bakker PAHM, Raaijmakers JM, Bloemberg GV, Hofte M, Lemanceau P, Cooke M (2007) New perspectives and approaches in plant growth-promoting rhizobacteria research. European Journal of plant pathology. 119:241242.

Barazani O, Friedman J (1999) Is IAA the major root growth factor secreted from plant-growth-mediating bacteria? Journal of Chemical Ecology. 25:2397-2406.

Buchenauer H (1998) Biological control of soil-borne diseases by rhizobacteria. Journal of Plant Diseases $e$ Protection. 105:329-348.

Cassán F, Perrig D, Sgroy V, Masciarelli O, Penna C, Luna V (2009) Azospirillum brasilense Az39 and Bradyrhizobium japonicum E109, inoculated singly or in combination, promote seed germination and early seedling growth in corn (Zea mays L) and soybean (Glycine max L). European Journal of Soil Biology. 45:28-35.

Cattelan AJ (1999) Métodos quantitativos para determinação de características bioquímicas e fisiológicas associadas com bactérias promotoras do crescimento vegetal. Londrina, December 1999.

Cerigioli MM (2005) Diversidade de bactérias endofíticas de raízes de milho (Zea mays L.) e potencial para promoção de crescimento. São Carlos. 1:1-132.

Chen YP, Rekha PD, Arun AB, Shen FT, Lai WA, Young CC (2006) Phosphate solubilizing bacteria from subtropical soil and their tricalcium phosphate solubilizing abilities. Appl Soil Ecol. 34: 33-41.

Crowley E, Bird P, Fisher K, Goetz K, Boyle M, Benzinger MJ, Jr, Juenger M, Agin J, Goins D (2012) Evaluation of the VITEK $^{\circledR} 2$ Gram-Negative (GN) Microbial Identification Test Card: Collaborative Study. Journal of AOAC International. 95:778-785.

Dastager SG, Deepa CK, Pandey A (2011) Potential, plant growth-promoting activity of Serratia nematodiphila NII0928 on black pepper (Piper nigrum L.). World Journal of Microbiology and Biotechnology. 27:259-265.

Fett WF, Osman SF, Dunn MF (1987) Auxin production by plant pathogenic Pseudomonads and Xanthomonads. Applied and Environmental Microbiology. 53:1839-1845.

Fuentes-Ramirez LE, Jimenez-Salgado T, Abarca-Ocampo IR, Cabalero-Mellado J (1993) Acetobacter diazotrophicus, an indole-acetic producing bacterium isolated from sugarcane cultivars of Mexico. Plant and Soil. 154:145-150.

Gao L, Kong F, Feng C, Wang J, Gao J, Shen G, Zhang C (2016) Isolation, Characterization, and Growth Promotion of Phosphate-Solubilizing Bacteria Associated with Nicotiana Tabacum (Tobacco). Pol. J. Environ. Stud. 25:993-1003

Gordon SA, Weber RP (1951) Colorimetric estimation of indoleacetic acid. Plant Physiology. 26:192-195.

Gholamalizadeh R, Khodakaramian G, Ebadi AA (2017) Assessment of Rice Associated Bacterial Ability to Enhance Rice Seed Germination and Rice Growth Promotion. Brazilian Archives of Biology and Technology. 60:1-13.

Gowtham HG, Singh SB, Niranjana SR (2015) Evaluation Of Plant Growth Promoting Ability Of Providencia spp. Collected From North Eastern Region Of India In Crucifers. International Journal of Agricultural Science and Research. 5:321-328. 
Hariprasad P, Niranjana SR (2009). Isolation and characterization of phosphate solubilizing rhizobacteria to improve plant health of tomato. Plant Soil. 316:13- 24.

Hayat R, Ali S, Amara U, Khalid R, Ahmed I (2010) Soil beneficial bacteria and their role in plant growth promotion. Annual Review of Microbiology. 60:579-598.

Hernández-Montiel LG, Chiquito-Contreras CJ, MurilloAmador B, Vidal-Hernández L, Quiñones-Aguilar EE, Chiquito-Contreras RG (2017) Efficiency of two inoculation methods of Pseudomonas putida on growth and yield of tomato plants. Journal of Soil Science and Plant Nutrition. 17:1003-1012.

Hickman FW, Steigerwalt AG, Farmer III JJ, Brenner DJ (1982) Identification of Proteus penneri sp. nov., formerly known as Proteus vulgaris indole negative or as Proteus vulgaris biogroup 1. Journal of Clinical Microbiology. 15:1097-1102.

Honda N, Hirai M, Ano T, Shoda M (1998) Antifungal effect of a heterotrophic nitrifier Alcaligenes faecalis. Biotechnology Letters. 20:703-705.

Iwamoto T, Tani K, Nakamura K, Suzuki Y, Kitagawa M, Eguchi M, Nasu M (2000) Monitoring impact of in situ biostimulation treatment on groundwater bacterial community by DGGE. FEMS Microbiology Ecology. 32:129141.

Jacobs A, Chenia HY (2009) Biofilm-forming capacity, surface hydrophobicity and aggregation characteristics of Myroides odoratus isolate from South African Oreochromis mossambicus fish. Journal of Applied Microbiology. 107:1957-1966.

Kavino M, Harish S, Kumar N, Saravanakumar D, Samiyappan R (2010) Effect of chitinolytic PGPR on growth, yield and physiological attributes of banana (Musa spp.) under field conditions. Applied Soil Ecology. 45:71-77.

Khalid A, Tahir S, Arshad M, Zahir ZA (2004) Relative efficiency of rhizobacteria for auxin biosynthesis in rhizosphere and non-rhizosphere soils. Australian Journal of Soil Research. 42:921-926.

Khan AR, Park G-S, Asaf S, Hong S-J, Jung BK, Shin J-H (2017) Complete genome analysis of Serratia marcescens RSC-14: A plant growth-promoting bacterium that alleviates cadmium stress in host plants. Plos One. 12:1-17.

Kimura M (1980) A simple method for estimating evolutionary rates of base substitutions through comparative studies of nucleotide sequences. Journal of Molecular Evolution. 16:111-120.

Lambrecht M, Okon Y, Broek AV, Vandereleyden J (2000) Indole-3-acetic acid: a reciprocal signaling molecule in bacteria-plant interactions. Trends in Microbiology. 8:298300.

Luster J, Göttlein A, Nowack B, Sarret G (2009) Sampling, defining, characterizing and modeling the rhizosphere - the soil science tool box. Plant Soil. 321:457-482.

Manos J, Belas R (2006) The genera Proteus, Providencia, e Morganella. Prokaryotes. 6:245-269.

Massenssini AM, Costa MD, Reis MR, Silva AA (2008) Atividade de isolados bacterianos solubilizadores de fosfato na presença de formulações comerciais de Glyphosate. Planta daninha. 26:815-823.

Matilla MA, Pizarro-Tobias $P$, Roca A, Fernandéz $M$, Duque $E$, Molina L, Wu X, Van Der Lelie D, Gómez MJ, Segura A, Ramos JL (2011) Complete genome of the plant growthpromoting rhizobacterium Pseudomonas putida BIRD-1. Journal of Bacteriology. 193:1290.
O'hara CM (2006) Evaluation of the Phoenix 100 ID/AST System and NID Panel for identification of Enterobacteriaceae, Vibrionaceae, and commonly isolated non enteric gram-negative bacilli. Journal of Clinical Microbiology. 44:928-933.

Oliveira VM, Sette LD, Fantinatti-Garboggini F (2006) Preservação e Prospecção de Recursos Microbianos. Multiciências. 7:1-19.

Oliveira AAR (2004) Rizobactérias em citros. Agronline.com.br. Available in: <http://www.agronline.com.br/artigos/artigo.php?id=145> Acess in: May 13, 2013.

Oliveira CA, Alves VMC, Marriel IE, Gomes EA, Scotti MR, Carneiro NP, Guimarães CT, Schaffert RE, Sá NMH (2009) Phosphate solubilizing microorganisms isolated from rhizosphere of maize cultivated in an oxisol of the Brazilian Cerrado Biome. Soil Biology and Biochemistry. 41:17821787.

Otto-Karg I, Jandl S, Muller T, Stirzel B, Frosch M, Hebestreit H, Abele-Horn M (2009) Validation of Vitek 2 Non fermenting Gram-Negative Cards and Vitek 2 Version 4.02 Software for Identification and Antimicrobial Susceptibility Testing of Nonfermenting Gram-Negative Rods from Patients with Cystic Fibrosis. Journal of Clinical Microbiology. 47:3283-3288.

Panhwar QA, Naher UA, Jusop S, Othman R, Latif MA, Ismail MR (2014) Biochemical and molecular characterization of potential phosphate-solubilizing bacteria in acid sulfate soils and their beneficial effects on rice growth. Plos One. 9:1-14.

Paternoster T, Défago G, Duffy B, Gessler C, Pertot I (2010) Selection of a biocontrol agent based on a potential mechanism of action: degradation of nicotinic acid, a growth factor essential for Erwinia amylovora. International Microbiology. 13:195-206.

Patten CL, Glick BR (2002) Role of Pseudomonas putida indole acetic acid in development of the host plant root system. Applied and Environmental Microbiology. 68:37953801.

Pedraza RO, Ramirez-Mata A, Xiqui ML, Baca BE (2004) Aromatic amino acid aminotransferase activity and indole3-acetic acid production by associative nitrogen-fixing bacteria. FEMS Microbiology Letters. 233:15-21.

Prathap M, Ranjitha Kumari BD (2015) A Critical Review on Plant Growth Promoting Rhizobacteria. J Plant Pathol Microb. 6:1-4.

Queiroz BPV, Melo IS (2006) Antagonismo de Serratia marcescens toward Phytophthora parasítica and its effects in promoting the growth of citrus. Brazilian Journal of Microbiology. 37:448-450.

Rocha DR, Fornasier Filho D, Barbosa JC (2011) Efeitos da densidade de plantas no rendimento comercial de espigas verdes de cultivares de milho. Horticultura Brasileira. 29:392-397.

Santosa S, Sutarno, Purwanto E, Suranto, Sajidan (2018) Molecular characterization of Plant Growth Promoting Rhizobacteria using 16S rRNA sequences in the organic rice field of Sukorejo Village, Central Java, Indonesia. Biodiversitas. 19: 2157-2162.

Sayyed RZ, Gangurde NS, Patel PR, Joshi SA, Chincholkar SB (2010) Siderophore production by Alcaligenes faecalis and it application for growth promotion in Arachis hypogea. Indian Journal of Biotechnology. 9:302-307. 
Silva Filho GN, Vidor C (2000). Solubilização de fosfatos por microrganismos na presença de fontes de carbono. Revista Brasileira de Ciência do Solo. 24:311-319.

Souchie EL, Azcón R, Barea JM, Saggin-Júnior OJ, Silva EMR (2005) Solubilização de fosfatos em meios sólido e líquido por bactérias e fungos do solo. Pesquisa Agropecuária Brasileira. 40:1149-1152.

Spaepen S, Vanderleyden J, Okon Y (2009) Plant growthpromoting actions of rhizobacteria. Advances in Botanical Research. 51:283-320.

Srinivasan M, Petersen DJ, Holl FB (1996) Influence of indoleacetic-acid-producing Bacillus isolates on the nodulation of Phaseolus vulgaris by Rhizobium etli under gnotobiotic conditions. Canadian Journal of Microbiology. 42:1006-1014.

Trabelsi D, Cherni A, Zineb AB, Dhane SF, Mhamdi R (2017) Fertilization of Phaseolus vulgaris with the Tunisian rock phosphate affects richness and structure of rhizosphere bacterial communities. Soil Ecology. 114:1-8.

Tripura C, Sashidhar B, Podile AR (2007) Ethyl methanesulfonate mutagenesis-enhanced mineral phosphate solubilization by groundnut-associated Serratia marcescens GPS-5. Current Microbiology. 54:79-84.
Tsavkelova EA, Cherdyntseva TA, Klimova SY, Shestakov Al, Botina SG, Netrusov Al (2007) Orchid-associated bacteria produce indole-3-acetic acid, promote seed germination, and increase their microbial yield in response to exogenous auxin. Archives of Microbiology. 188:655-664.

Vazquez P, Holguin G, Puente ME, Lopez-Cortes A, Bashan Y (2000) Phosphate-solubilizing microorganisms associated with the rhizosphere of mangroves in a semiarid coastal lagoon. Biology and Fertility of Soils. 30:460-468.

Verma SC, Ladha JK, Tripathi AK (2001) Evaluation of plant growth promoting and colonization ability of endophytic diazotrophs from deep water rice. Journal of Biotechnology. 91:127-141.

Xie H, Pasternak JJ, Glick BR (1996) Isolation and characterization of mutants of the plant growth-promoting rhizobacterium Pseudomonas putida GR12-2 that overproduce indoleacetic acid. Current Microbiology. 32:67-71.

Yamada EA, Alvim ID, Santucci MCC, Sgarbieri VC (2003) Composição centesimal e valor protéico de levedura residual da fermentação etanólica e de seus derivados. Revista de Nutrição. 16:423-432. 